1 Black LF, Hyatt RE. Maximal inspiratory pressures: normal values and relationship to age and sex. Am Rev Respir Dis 1969;99:696-702.

2 Arora NS, Rochester DF. Respiratory muscle strength and maximal voluntary ventilation in undernourished patients. Am Rev Respir Dis 1982;126:5-8.

3 Gibson GJ, Pride NB, Newson-Davis J, Loh LC. Pulmonary mechanics in patients with respiratory muscle weakness. Am Rev Respir Dis 1977;115:389-95.

4 Byrd RB, Hyatt RE. Maximal respiratory pressures in chronic obstructive lung disease. Am Rev Respir Dis 1968;98:848-56.

5 Smyth RJ, Chapman KR. Maximal inspiratory and expiratory pressures in adolescents. Normal values. $A m$ Rev Respir Dis 1987;136:1285-98.

6 Leech JA, Ghezzo H, Stevens D, Becklake MR. Respiratory pressures and function in young adults. Am Rev Respir Dis 1983;128:17-23.

7 Wagener JS, Hibbert ME, Landau LI. Maximal respiratory pressures in children. Am Rev Respir Dis 1984;129:873-5.

8 Wilson SH, Cooke NT, Edwards RHT, Spiro SG. Predicted normal values for maximal respiratory pressures in caucasian adults and children. Thorax 1984;39:535-8.
9 Standardization of spirometry 1987 update. Am Rev Respir Dis 1987;136:1285-8.

10 Ferris BJ. Epidemiology standardization project. Am Rev Respir Dis 1978;6 (part 2):7-35.

11 Roca J, Sanchis J, Agusti-Vidal A, Segarva F, Navajas D, Rodriguez-Roisin R, et al. Spirometric reference from a Mediterranean population. Bull Eur Physiopathol Respir 1986;22:217-24.

12 Cook CD, Mead J, Orzalezi NM. Static volume pressure characteristic of the respiratory system during maximum efforts. J Appl Physiol 1964;19:1016-21.

13 Koulouris N, Mulvey DA, Larroche CM, Green M, Moxhan $J$. Comparison of two different mouthpieces for the measurement of $\mathrm{PI}_{\max }$ and $\mathrm{PE}_{\max }$ in normal and weak subjects. Eur Respir J 1988;1:863-7.

14 Rubinstein I, Slutsky AS, Rebuck AS, McClean PA, Boucher R, Szeinberg A, et al. Assessment of maximal expiratory pressure in healthy adults. $J$ Appl Physiol 1988;64 (5):2215-9.

15 Rochester DF, Braun NMT, Lane S. Diaphragmatic energy expenditure in chronic respiratory failure; the effect of assisted ventilation with body respirators. $\mathrm{Am} \mathrm{J} \mathrm{Med}$ 1977;63:223-32.

\title{
Adventitia
}

\section{A journey to Sakti}

The well ordered life of a pathologist can be disrupted if he falls into the hands of adventurous clinicians. I was never meant by build or inclination to cavort in mountains at high altitude but my long association with Peter Harris determined otherwise. He and Inder Anand became fascinated with the problem of the responses to hypoxia of the pulmonary circulation of the offspring of yaks and cattle in the Himalayas. Yaks are genetically adapted to hypobaric hypoxia and have a low pulmonary arterial pressure. Cattle have to acclimatise to high altitude and develop pulmonary hypertension. They were keen to study the dzo resulting from this union of adapted and acclimatised species and the stol produced by the crossing of dzos and cattle. David Williams and I were invited to travel to the village of Sakti in the Karakorams, in an area of Ladakh at $4000 \mathrm{~m}$ known as Little Tibet, to join these clinicians in their investigation.

It was thought prudent to have a trial run with cardiac catheterisation of two yaks from a herd in England before using the technique on the mountainside. The keeper thought we were deranged even to attempt it and said that, although he fed his yaks every day, he would not risk getting in among them. His sentiments were justified, for the first animal, just 11 months old, suddenly flexed his hindquarters during the procedure and catapulted one of the party through the air to crash into a concrete wall several feet away. In Sakti the yaks were in the charge of the chief herdsman of the village. During cardiac catheterisation they stood motionless under his eagle eye and Peter was able to get excellent tracings. Clearly the best place to study wild and independently minded yaks was in England.

Three attempts to fly to a nearby airstrip at Leh were abandoned by pilots, who would not face the cross winds. Inder organised our party in three small cars to cross the Himalayas, but the winter snows had not melted and the local commander of the army post at the foot of the great mountains would not open the barrier for cars to gain access to the pass. A struggle between clinical science and the Indian Army ensued. As dusk fell a great crowd of Indian drivers with their cars, anxious to get through, assembled around their new found cardiologist leader. In the light of a hundred torches Inder conversed on the telephone with a senior army officer at his headquarters. Each development in the conversation was transmitted to the crowd, which responded periodically with bursts of cheering. The pulmonary circulation triumphed and it was agreed that the pass would be opened at first light on the morrow. We spent the night on the floor of a nearby inn.

Our studies were carried out in a building opposite the Buddhist Tak Tok gompa in Sakti. Each morning, after starting their day with the sounding of trumpets and deep throated horns, the monks in their saffron robes would leave their religious rites and stroll over to see what these alien visitors to their village were up to. The locals were at first deeply suspicious but the ice was broken when a small boy was brave enough to bring his painfully thin pet rabbit to Peter, who took a picture of it with his polaroid camera. This was immediately taken off by the owner and was followed by a remarkable influx of the small boys from the surrounding mountains.

The remote and isolated mountain environment and the Buddhist influence of oppressive quietness and calm amidst the prayer wheels and constantly flapping prayer flags had their effect. Peter became contemplative and given to long, solitary walks in the mountains and the painting of water colours of the animals. Inder, being a Sikh, cast increasingly envious glances at the cattle, regarding them more as owners of a fascinating pulmonary circulation worthy of investigation than as objects of religious reverence. Tension and headaches developed in this ethereal atmosphere and made it difficult to decide whether they were an expression of acute mountain sickness or of unquiet minds. When I found David one morning sitting uncommunicative with his head in his hands I knew the expedition had run its course. Eventually we flew out and I was able to luxuriate in the seat belts that had mysteriously lengthened during my stay in the mountains. I felt no regret at seeing the Karakorams slip away below and I found myself looking forward to returning to the teeming mass of humanity of the fish market in Delhi.-DONALD HEATH 